\title{
Diversity and conservation status of native Australian bees*
}

\author{
Michael BATLEY $^{1}$, Katja HogENDOORN ${ }^{2}$ \\ ${ }^{1}$ Australian Museum, 6 College St, Sydney, N.S.W., 2010, Australia and Department of Biological Sciences, \\ Division of Environmental and Life Sciences, Macquarie University, North Ryde, N.S.W. 2109, Australia \\ ${ }^{2}$ School of Agriculture, Food and Wine, University of Adelaide, SA 5005, Australia
}

Received 8 August 2008 - Revised 14 October 2008 - Accepted 26 October 2008

\begin{abstract}
Australia's idiosyncratic bee fauna is characterised by a combination of numerous endemic taxa and by the complete absence of some families. Many species, and in particular several oligolectic species, remain undescribed and more than half the named taxa are in need of revision. The main threats to the native bee fauna include removal of nesting and foraging opportunities through land clearing and agriculture, the spread of exotic plant species and the consequences of climate change. Early steps to conserve the native bee fauna include commercial applications, the raising of public awareness and preservation of natural habitat. However, these actions are severely hampered by a lack of both identification keys and taxonomic expertise. Considerable investment in taxonomic research is needed to improve this state of affairs.
\end{abstract}

native bees / Australia / conservation / taxonomy / Apoidea

\section{DIVERSITY OF BEES IN AUSTRALIA}

Australia has a distinctive bee fauna characterized by an unusually high proportion of species in the family Colletidae (Tab. I). Several groups with widespread distributions throughout the rest of the World, notably Andrenidae and Mellitidae, are not found in Australia while the family Stenotritidae, and the subfamily Euryglossinae are endemic to the region (Michener, 1965, 2000). More than three-quarters of the known species belong to the three most highly derived bee families, Stenotritidae, Colletidae and Halictidae (Danforth et al., 2006) and a small number of colonisation events have given rise to lineages, like the genus Exoneura (Schwarz et al., 2006) or parts of the genus Lasioglossum (Danforth and $\mathrm{Ji}, 2001$ ), that are endemic to Australia and adjacent areas. Despite the incomplete nature of flower-visiting records, approximately

Corresponding author: K. Hogendoorn, katja.hogendoorn@adelaide.edu.au

* Manuscript editor: Mark Brown
100 bee species are either known or suspected to be oligolectic (AFD, 2006).

Michener (1965) noted a clear difference between the "typically Australian element" found throughout most of the continent and the depauperate bee fauna of the northern rainforests that shares features with that of New Guinea and the Indo-Malaysian region. At the species level, there is a less distinct division between the fauna of the open eucalypt forests and woodland of eastern and southeastern coastal regions and that of the arid zone which covers most of the remaining area. There are no sharp lines of demarcation and species belonging to groups with significant diversity in New Guinea have been found in rainforest remnants as far south as Sydney.

While the taxonomy of Australian bees has received some attention in the last 20 years, there is still a large number of undescribed species. The Australian Faunal Directory (AFD, 2006) lists 1647 names, of which about $45 \%$ come from revisions published after 1965, 18\% have been treated in doctoral theses that remain unpublished, and the 
Table I. The number of Australian genera and named species (AFD, 2006) covered by keys. References to the keys are given in Michener (2000).

\begin{tabular}{lccccc}
\hline family & \# genera & $\begin{array}{c}\text { \# genera with keys } \\
\text { to at least part }\end{array}$ & $\begin{array}{c}\text { \# named } \\
\text { species }\end{array}$ & $\begin{array}{c}\text { \# species covered } \\
\text { by keys }\end{array}$ & $\begin{array}{c}\text { \% of species covered } \\
\text { by keys }\end{array}$ \\
\hline Apidae & 13 & 4 & 197 & 49 & $25 \%$ \\
Colletidae & 31 & 20 & 879 & 434 & $49 \%$ \\
Halictidae & 11 & 3 & 385 & 188 & $49 \%$ \\
Megachilidae & 5 & 1 & 168 & 25 & $15 \%$ \\
Stenotritidae & 2 & 1 & 21 & 10 & $48 \%$ \\
\hline
\end{tabular}

remaining $37 \%$ are greatly in need of revision. Genera such as Exoneura, Lipotriches, Stenotritus, Paracolletes, Trichocolletes and much of Euhesma have not been studied in recent times.

Extrapolation of the results of four recent investigations, including unpublished theses, covering almost $30 \%$ of the fauna suggests that between 300 and 400 species remain undescribed, but that the total number of valid names will remain virtually unchanged when synonyms are removed. However, not only are there large uncertainties in such extrapolations, but there is probably a bias towards polylectic species. Oligolectic species are often overlooked until the nature of their specialisation is discovered (Houston, 1989, 1992, 1993; Exley 1998, 2004; reviewed in Murray et al., 2009).

A measure of the extent of missing information is given by the number of subgenera for which there are no published keys to species (Tab. I). Overall, 57\% of all named species are not covered by keys.

Knowledge of the taxonomy of Australian bees is much more extensive than information about their biology. Many species are known from very few specimens and distributions and flowering-visiting records for regions outside Western Australia are limited (Houston, 2000: AFD, 2006).

\section{THREATS TO BEES IN AUSTRALIA}

\subsection{Deforestation and agriculture}

The loss of floral resources and nesting sites associated with deforestation will obviously affect bee populations, with demonstrable economic consequences (Kremen et al., 2004). Similar studies have shown that the presence of native Australian rainforest is important for the unmanaged pollination of tropical fruit (Blanche et al., 2006).

Conservation of native vegetation in Australia has received considerable public and regulatory attention over the past 20 years, primarily with the objectives of controlling secondary dryland salinity, maintaining biodiversity and reducing greenhouse gas emissions. A recent review of progress towards national objectives for biodiversity conservation (Griffin NRM Pty Ltd., 2004) concluded that, despite patchy success in many areas, clearing of native vegetation will be effectively controlled in most jurisdictions by 2010 , provided that currently proposed and enacted regulations are properly implemented. Australia is still some distance from achieving a no net loss target for native vegetation, but the recent policy and regulatory interventions should ensure that all future clearing proposals are subject to appropriate levels of assessment relative to the conservation status of the vegetation community.

Some areas have been less affected by clearing than others so that only $13 \%$ of the total land area has been cleared. The largest proportion of Australia, the rangelands of the arid zone, remains relatively free of broadscale clearing. The eastern and south-eastern coastal areas were predominantly eucalyptus forests and woodlands. Approximately $80 \%$ of the pre-European extent of eucalypt forests and woodlands remain, despite high rates of clearing in Queensland and New South Wales that were a cause for concern. Between 1981 and 1999 the average rate of clearing was 
$38000 \mathrm{ha} /$ year in NSW and $343000 \mathrm{ha} /$ year in Queensland, though some of this was removal of regrowth. The most severely affected vegetation groups are the low closed forests, closed shrublands and the heaths, of which only $50 \%$ now remains, but these covered only $1 \%$ of the continental area.

However, vegetation removal is not the only form of ecological disturbance and an area may retain the same vegetation type and yet have a different species composition. For example, it has been estimated that of the two million ha of lowland grassland in southeastern Australia at the time of European settlement, the remaining natural remnants cover 10000 ha. (McDougall and Kirkpatrick, 1994). Furthermore, in the arid centre of Australia, substantial changes in plant composition have been attributed to the impacts of water-centred grazing. The effect of such changes on bee populations could be considerable. For example in the southern arid regions of Australia, the lack of regeneration of Western Myall due to rabbit, goat and sheep grazing (Lange and Purdie, 1976), may seriously affect the survival of the endemic allodapine bee $E x$ oneurella tridentata, because this species depends largely on the dead branches of this tree for nesting substrate (Hurst, unpubl. data). This is an important issue, because E. tridentata is the only known eusocial bee species outside the Apinae that has allometric castes (Houston, 1977). However, the extent to which these changes in the landscape have influenced the distribution and biology of bee species will never be known, because both information on the status quo before human intervention and on the current situation are seriously deficient.

Floral diversity may also be important for bees (Murray et al., 2009). It has been suggested (Bernhardt, 1987) that many Acacia species require the presence of co-blooming nectiferous flowers if bee populations are to be supported.

There is also an absence of information about the impact of agricultural pesticides on bee populations. While it is tempting to blame pesticide use for low bee densities, large-area agriculture itself may be responsible. Areas devoted to the production of cereal crops may support few bees because of the absence of nectar-producing flowers, making pesticides of secondary importance.

\subsection{Exotic species}

Australia is the only country yet to be invaded by Varroa destructor and has a large population of feral Apis mellifera. The numbers of feral honeybees are such that they may be affecting the populations of birds, mammals and other insects by virtue of the sheer amount of floral resources that they consume (Paton, 1996; Stout and Morales, 2009). Paini (2004) has reviewed the 10 studies that addressed various aspects of the impact of European honeybees on native bees in Australia and concluded that many of the studies suffered from low replication or confounding factors. It is likely that the most important impact of honeybees on native bees is indirect, through their role in the propagation of serious exotic weeds such as Scotch Broom (Cytisus scoparius, Simpson et al., 2005), and lantana (Lantana camara, Goulson and Derwent, 2004) at the cost of native vegetation (Stout and Morales, 2009). The imminent arrival of the Varroa mite in Australia, which is expected to largely wipe out feral honeybees, will provide an interesting opportunity to investigate the impact of feral honeybees on the native flora and fauna.

A second exotic species of concern (Hingston and McQuillan, 1998; Hingston et al., 2002) is Bombus terrestris which has become widespread on the island state of Tasmania since its introduction in 1992, and has been shown to displace native bees from flowers (Hingston and McQuillan, 1999). However, again the main reason for concern about this incursion lies in the fact that this species is likely to increase the seed production of some weeds and sleeper weeds (Goulson, 2003; Stout and Morales, 2009), which will in turn influence the native bee fauna.

As an island continent, Australia has a natural advantage for the exclusion of exotic species and has a strong quarantine system in operation. Strict protocols were adopted to ensure that the importation of Megachile rotundata for pollination of alfalfa did not 
bring exotic parasites and diseases (Anderson, 2006). Quarantine procedures were, however, unable to prevent introduction of the Emerald Furrow Bee, Halictus smaragdulus, which has been found in the Hunter Valley of New South Wales (Gollan et al., 2008) and the Carder Bee, Afranthidium repetitum (Walker, 2008) which has become common over a wide area around Brisbane. Specimens of both have now been found in Sydney (MB, unpubl. data).

\subsection{Climate and climate change}

Much of Australia has an unstable environment, with large variations in rainfall. Floods are common in the north of the country and can wipe out aggregations of ground nesting bees (e.g. Fellendorf et al., 2004). While climate change is expected to increase the frequency of such events and adverse effects are expected for ecosystems like rainforests and alpine regions, it is more difficult to foresee the impact on other areas (Murray et al., 2009). One firm prediction is that bushfires, which often destroy large areas of native woodland, will become more frequent and of greater severity. Bushfire management is a major social issue in Australia with competing demands of property protection and environmental conservation. A number of investigations have been undertaken (e.g., Auld, 2001; Auld and Denham, 2006) to assess the effect of fire frequency on plants, but the consequences for bees in unknown. It is suspected that the carpenter bee Xylocopa aeratus has become extinct in Victoria through a combination of land clearing and burning of the areas that are currently still suitable to support a population (Leijs, unpubl. data). An increase in temperature through global warming will no doubt exacerbate these problems. Furthermore, in response to the drought, urban gardeners and parks management have taken to extensive mulching of bare soil. Although this is a commendable strategy to achieve water conservation, it has caused the loss of numerous aggregations of ground nesting bees ( $\mathrm{MB}$ and $\mathrm{KH}$, unpubl. data).

\section{PRESERVATION OF NATIVE BEES IN AUSTRALIA}

There are two possible strategies for conserving existing bee species - development of commercial applications and the development of public interest. Early steps have been taken in both directions.

Concern about the potential loss of pollination services by feral honeybees that would follow the arrival of Varroa mites in Australia has resulted in a recommendation to the government to fund research into possible ways of dealing with this incursion. The recommendations include investigation of native species that could be used as alternatives to Apis for certain crops. Although doubts about the possibility have been expressed (Gordan and Davis, 2003), solitary bees are successfully used in several crops overseas (Delaplane and Mayer, 2000) and methods for the development of bees as crop pollinators are well established (Bosch and Kemp, 2002). The sceptics may have overlooked the possibility that an important constraint on native populations may be set by the availability of nesting sites (Steffan-Derwenter and Schiele, 2008; Kremen et al., 2004), a limitation that might be overcome without too much difficulty. Recent research shows that both Australian Xylocopa and Amegilla are useful pollinators for tomato in greenhouses (Bell et al., 2006; Hogendoorn et al., 2000, 2006, 2007). Stingless bees can be used as pollinators of several tropical crops such as macadamia and mango (Heard, 1999). Preliminary research on the use of six native megachilid species as pollinators for Lucerne pollination (Bray, 1973) demonstrated their efficiency as pollinators of this crop, but the study was not followed up due to a lack of suitable techniques for propagation and manipulation of the activity patterns, which have now been developed overseas (e.g. Bosch and Kemp, 2002).

The level of public interest in conservation of Australian native bee species is quite high and it should be possible to build up support both for general conservation measures and for development of urban areas as refugia (Tomassi et al., 2004). Dr Anne Dollin has for many years promoted their conservation and 
exploitation through the Australian Native Bee Research Centre and there is an active Yahoo interest group whose members regularly exchange pictures and news via the internet. In October 2006, a two day workshop on native bees attracted 50 participants from all over the country and occasional talks on the subject of native bees are usually well-attended. At least one local Council is actively encouraging its rate-payers to keep Trigona carbonaria hives in their gardens. Australian suburban areas are generally well vegetated and likely to sustain greater bee diversity than more densely populated cities (Matteson et al., 2008).

Bees will, of course, benefit from conservation measures of a more general nature, like the reduction of vegetation clearance or the establishment of the $2800 \mathrm{~km}$ wildlife corridor along almost the entire east coast of Australia, allowing plants and animals to move as climate changes.

The major constraint on bee conservation, however, is the severe shortage of information and expertise. The authors of the Australian Terrestrial Biodiversity Assessment (Sattler and Creighton, 2002) found that "data on invertebrates are patchy: conclusions cannot be drawn at the Australia-wide scale".

The need for expertise is just as urgent. Examination of the list of 76 designated wildlife refugia in arid and semi-arid areas (Morton et al., 1995) reveals that no Hymenoptera were included among the invertebrates to be protected in these areas, though many species of gastropods and pseudo-scorpions were mentioned. It must be concluded that advocacy by taxonomists and ecologists with an interest in bees will be an essential element in achieving practical conservation.

National policy makers have adopted the ecosystem services concept (Cork et al., 2007), which will require the acquisition of a great deal more experimental information about bee biology to provide a reasonable basis for decision making (Kremen et al., 2007). Without such information, analysis of the ecosystem service is likely to be oversimplified (Cork et al., 2007) with undesirable consequences. However, with many undescribed species and the overall lack of adequate identification keys (Tab. I), the data that are needed can only be supplied by expert taxonomists. The recent, sad loss of Professor Elizabeth Exley has deprived us of a major contributor to both the taxonomy of Australian bees and the training of Australian taxonomists. The country now has six living bee taxonomists with an average age of well over fifty, but only two are employed in positions that would permit even limited time for bee taxonomy. A number of government-funded projects designed to improve public access to available information are in the pipeline, which will only increase the need for fundamental taxonomic data. Unless there is a concerted effort to provide training and employment in the appropriate skill areas, the information of the conservation status of Australian native bees will not become available, and moreover the present capacity will be lost.

\section{CONCLUSIONS}

Australia has an extensive and interesting bee fauna, which is currently threatened by large scale agriculture and possibly by changes in climate. Of major concern is the absence of basic information about the biology of the bee fauna. Although the majority of species are polylectic, it is the significant minority of oligolectic species that are most under threat (Zayed et al., 2005; Zayed, 2009) and most likely to have difficulty adapting to new hosts (Praz et al., 2008). Many oligolectic species may remain undiscovered. More importantly, information about distribution and breeding behaviour of the majority of species is incomplete. Species are constantly being found in areas where they were previously unknown (MB, unpubl. data)

There is an urgent need to train and create employment opportunities for taxonomists and for a large scale survey of Australia's existing bee fauna, in particular in view of the potentially important role for native bees as crop pollinators.

\section{ACKNOWLEDGEMENTS}

We thank Rob Paxton and Mark Brown for their editorial role, and Remko Leijs for valuable discussion and suggestions. 


\section{Diversité et statut de conservation des abeilles in- digènes australiennes.}

\author{
Apoidea / abeille indigène / Australie / protec- \\ tion / taxonomie
}

\section{Zusammenfassung - Diversität und Schutz- status der einheimischen Bienen Australi-} ens. Australien besitzt eine einzigartige Bienenfauna, die sich durch einen hohen Anteil an Arten der Familie Colletidae und das Fehlen von Andrenidae und Mellitidae auszeichnet. Aufgrund einer geringen Anzahl an Kolonisierungsereignissen sind viele Linien endemisch. Schätzungsweise $25 \%$ der Arten sind noch unbeschrieben und $50 \%$ der Taxa bedürfen einer Revision. Insbesondere viele oligolektische Arten könnten übersehen worden und aufgrund fehlender Schutzmassnahmen bedroht sein. Des weiteren sind für insgesamt $57 \%$ der Arten keine Bestimmungsschlüssel verfügbar. Dies stellt ein schwerwiegendes Hindernis für Untersuchungen der einheimischen Bienen durch Laien oder Nichtextperten dar. Informationen zum Blütenbesuch und zum Nistverhalten gibt es nur für einige wenige Arten.

Die vielfachen Bedrohungen der einheimischen Bienenfauna beinhaltet die Entfernung von Nistgelegenheiten und Futtersammelstellen, die Ausbreitung eingeführter exotischer Pflanzenarten und Klimaveränderungen. Grossflächige Beseitigungen der natürlichen Vegetation für landwirtschaftliche Zwecke sind zwar im Rückgang, die Veränderungen in der Zusammensetzung der Flora sind jedoch ein Grund zur Sorge. Diese Veränderungen rühren von der Beweidung durch Vieh und andere eingeführte Säugetiere her, sowie durch den Ersatz einheimischer Pflanzen durch eingeführte Unkräuter. Letztere profitieren in ihrer Bestäbung nicht zuletzt von ausgewilderten oder beimkerten Honigbienenvölkern. Die direkte Konkurrenz zwischen einheimischen Bienen und Honigbienen ist vermutlich variabel und abhängig von den jeweils verfügbaren Pflanzen als Nahrungsquellen.

Klimaveränderungen führen zu vermehrten Überschwemmungen und Buschfeuern und haben als langfristige Konsequenz unvorhersehbare Veränderungen in der floralen Abundanz und Phänologie zur Folge. All diese Faktoren beeinflussen mit grosser Wahrscheinlichkeit die Verteilung und Häufigkeit der einheimischen Bienen. Einleitende Schritte zum Schutz der einheimischen Bienenfauna könnten ihre Nutzung als Bestäuber von Nutzpflanzen sein, sowie die Anhebung des öffentlichen Bewusstseins über den Schutz natürlicher Habitate. Der allgemeine Mangel an Kenntnissen über die Taxonomie und das Fehlen von Bestimmungsschlüsseln sind hierin jedoch schwerwiegende Hinderungsgründe. Unsere Fähigkeit des Monitoring und der Beurteilung des
Schutzstatus der einheimischen Bienen Australiens erfordert die Ausbildung und die Einstellung von Bienentaxonomen. einheimische Bienen / Australien / Schutzstatus /
Taxonomie

\section{REFERENCES}

AFD (2006), Cardale J.C. (2001) Updated by Walker K.L. (2006) Hymenoptera: Apoidea, Australian Faunal Directory, Australian Biological Resources Study, Canberra. http://www.environment.gov. au/biodiversity/abrs/online-resources/fauna/afd/ taxa/APOIDEA/checklist (accessed 12 February 2009).

Anderson D. (2006) Improving lucerne pollination with leafcutter bees stage 2, Rural Industries Research and Development Corporation, Canberra. [online] http://www.rirdc.gov.au/ reports/PSE/06-108.pdf (accessed on 30 January 2009).

Auld T.D. (2001) The ecology of the Rutaceae in the Sydney region of south-eastern Australia: poorly known ecology of a neglected family, Cunninghamia 7, 213-239.

Auld T.D., Denham A.J. (2006) How much seed remains in the soil after a fire? Plant Ecol. 187, 1524.

Bell M.C., Spooner-Hart R.N., Haigh A.M. (2006) Pollination of greenhouse tomatoes by the australian bluebanded bee Amegilla (Zonamegilla) holmesi (Hymenoptera:Apidae), J. Econ. Entomol. 99, 437-442.

Bernhardt P. (1987) A comparison of the diversity, density and foraging behaviour of bees and wasps on Australian Acacia, Ann. Mo. Bot. Gard. 74, 4250.

Blanche K.R., Ludwig J.A., Cunningham S.A. (2006) Proximity to rainforest enhances pollination and fruit set in orchards, J. Appl. Ecol. 43, 1182-1187.

Bosch J., Kemp W.P. (2002) Developing and establishing bee species as crop pollinators: the example of Osmia spp. (Hymenoptera: Megachilidae) and fruit trees, Bull. Entomol. Res. 92, 3-16.

Bray R.A. (1973) Characteristics of some bees of the family Megachilidae in Southeast Queensland and their potential as alfalfa pollinators, J. Aust. Entomol. Soc. 12, 99-102.

Cork S., Stoneham G., Lowe K. (2007) Ecosystem services and Australian natural resource management (NRM) futures: Paper to the Natural Resource Policies and Programs Committee (NRPPC) and the Natural Resource Management Standing Committee (NRMSC), Australian Government Department of the Environment, Water, Heritage and the Arts, Canberra. 
Danforth B.N., Ji S. (2001) Australian Lasioglossum + Homalictus form a monophyletic group: resolving the "Australian Enigma", Syst. Biol. 50, 268-283.

Danforth B.N., Sipes S., Fang J., Brady S.G. (2006) The history of early bee diversification based on five genes plus morphology, Proc. Natl. Acad. Sci. USA 103, 5118-5123.

Delaplane K.S., Mayer D.F. (2000) Crop pollination by bees, CABI Publishing, New York.

Exley E.M. (1998) New Euryglossa (Euhesma) bees (Hymenoptera: Apoidea: Euryglossinae) associated with the Australian plant genus Eremophila (Myoporaceae), Rec. West. Aust. Mus. 18, 419437.

Exley E.M. (2004) Revision of the genus Dasyhesma Michener (Apoidea: Colletidae: Euryglossinae), Rec. West. Aust. Mus. 22, 129-146.

Fellendorf M., Mohra C., Paxton R.J. (2004) Devasting effects of river flooding to the ground-nesting bee, Andrena vaga (Hymenoptera: Andrenidae), and its associated fauna, J. Insect Conserv. 8, 311-312.

Gollan J.R., Batley M., Reid C.A.M. (2008) The exotic bee Halictus smaragdulus Vachal, 1895 (Hymenoptera: Halictidae) in the Hunter Valley, N.S.W.: A new genus in Australia, Aust. Entomol. 35, 21-26.

Gordon J., Davis L (2003) Valuing honeybee pollination, Rural Industries Research and Development Corporation, Canberra. [online] http://www.rirdc. gov.au/reports/HBE/03-077.pdf (accessed on 30 January 2009).

Goulson D. (2003) Effects of introduced bees on native ecosystems, Annu. Rev. Ecol. Syst. 34, 1-26.

Goulson D., Derwent L.C. (2004) Synergistic interactions between an exotic honeybee and an exotic weed: pollination of Lantana camara in Australia, Weed Res. 44, 195-202.

Griffin NRM Pty Ltd. (2004) Small steps for nature: A review of progress towards the National Objectives and Targets for Biological Diversity Conservation 2001-2005, WWF Australia and Humane Society International, Sydney.

Heard T.A. (1999) The role of stingless bees in crop pollination, Annu. Rev. Entomol. 44, 183-206.

Hingston A.B., McQuillan P.B. (1998) Does the recently introduced bumblebee Bombus terrestris (Apidae) threaten Australian ecosystems? Aust. J. Ecol. 23, 539-549.

Hingston A.B., McQuillan P.B. (1999) Displacement of Tasmanian native megachilid bees by the recently introduced bumblebee Bombus terrestris (Linaeus, 1758) (Hymenoptera: Apidae), Aust. J. Zool. 47, 59-65.

Hingston A.B., Marsden-Smedley J., Driscoll D.A., Corbett S., Fenton J., Anderson R., Plowman C., Mowling F., Jenkin M., Matsui K., Bonham K.J., Ilowski M., McQuillan P.B., Yaxley B., Reid
T., Storey D., Poole L., Mallick S.A., Fitzgerald N., Krirkpatrick J.B., Febey J., Harwood A.G., Michaels K.F., Russell M.J., Black P.G., Emerson L., Visoiu M., Morgan J., Breen S., Gates S., Bantich M.N., Desmachelier J.M. (2002) Extent of invasion of Tasmanian native vegetation by the exotic bumblebee Bombus terrestris (Apoidea: Apidae), Aust. Ecol. 27, 162-172.

Hogendoorn K., Steen Z., Schwarz M.P. (2000) Native Australian carpenter bees as a potential alternative to introducing bumble bees for tomato pollination in greenhouses, J. Apic. Res. 39, 67-74.

Hogendoorn K., Gross C.L., Sedgley M., Keller M.A. (2006) Increased tomato yield through pollination by native Australian Amegilla chlorocyanea (Hymenoptera: Anthophoridae), J. Econ. Entomol. 99, 828-833.

Hogendoorn K., Coventry S.A., Keller M.A. (2007) Foraging behaviour of a blue banded bee, Amegilla (Notomegilla) chlorocyanea Cockerell in greenhouses: implications for use as tomato pollinators, Apidologie 38, 86-92.

Houston T.F. (1977) Nesting biology of three allodapine bees in the subgenus Exoneurella Michener (Hymenoptera: Anthophoridae), Trans. R. Soc. S. Aust. 104, 99-113.

Houston T.F. (1989) Leioproctus bees associated with Western Australian smoke bushes (Conospermum sp.) and their adaptations for foraging and concealment (Hymenoptera: Colletidae: Paracolletini), Rec. West. Aust. Mus. 14, 275-292.

Houston T.F. (1992) Three new, monolectic species of Euryglossa (Euhesma) from Western Australia (Hymenoptera: Colletidae), Rec. West. Aust. Mus. 15, 719-728.

Houston T.F. (1993) Apparent mutualism between Verticordia nitens and V. aurea (Myrtaceae) and their oil-ingesting bee pollinators (Hymenoptera: Colletidae), Aust. J. Bot. 41, 369-380.

Houston T.F. (2000) Native bees on wildflowers in Western Australia. A synopsis of bee visitation of wildflowers based on the bee collection of the Western Australian Museum, Special Publication No. 2, Western Australian Insect Study Society, Perth.

Kremen C., Williams N.M., Bugg R.L., Fay J.P., Thorp R.W. (2004) The area requirements of an ecosystem service: crop pollination by native bee communities in California, Ecol. Lett. 7, 1109-1119.

Kremen C., Williams N.M., Aizen M.A., GemmillHerren B., LeBuhn G., Minckley R.L., Packer L., Potts S.G., Roulston T., Steffan-Dewenter I., Vázquez D.P., Winfree R., Adams L., Crone E.E., Greenleaf S.S., Keitt T.H., Klein A.-M., Regetz J., Ricketts T.H. (2007) Pollination and other ecosystem services produced by mobile organisms: a conceptual framework for the effects of land-use change, Ecol. Lett. 10, 299-314. 
Lange R.T., Purdie R. (1976) Western myall (Acacia sowdenii) its survival prospects and management needs, Aust. Rangeland J. 1, 64-69.

McDougall K., Kirkpatrick J.B. (1994) Conservation of lowland native grasslands in South-eastern Australia, World Wild Fund for Nature Australia, Sydney.

Matteson K.C., Ascher J.S., Langellotto G.A. (2008) Bee richness and abundance in New York City urban gardens, Ann. Entomol. Soc. Am. 101, 140150.

Michener C.D. (1965) A classification of the bees of the Australian and South Pacific regions, Bull. Am. Mus. Nat. Hist. 130, 1-362.

Michener C.D. (2000) The bees of the world, John Hopkins University Press, Baltimore.

Morton S.R., Short J., Barker R.D. (1995) Refugia for biological diversity in arid and semi-arid Australia, Paper No. 4, Biodiversity Unit, Australian Government Department of the Environment, Water, Heritage and the Arts, Canberra. [online] http://www.environment. gov.au/publications/series/paper4/index.html (accessed on 30 January 2009).

Murray T.E., Kuhlmann M., Potts S.G. (2009) Conservation ecology of bees: populations, species and communities, Apidologie 40, 211236.

Paton D.C. (1996) Overview of the feral and managed honeybees of Australia: distribution, abundance, extent of interactions with native biota, evidence of impacts and future research, Australian Nature Conservation Society, Melbourne.

Paini D.R. (2004) Impact of the introduced honey bee (Apis mellifera)(Hymenoptera: Apidae) on native bees: a review, Aust. Ecol. 29, 399-407.
Praz C.J., Müller A., Dorn S. (2008) Specialised bees fail to develop on non-host pollen: do plants chemically protect their pollen? Ecology (Wash. DC) 89, 795-804.

Sattler P., Creighton C. (2002) Australian terrestrial biodiversity assessment 2002, Department of the Environment, Water, Heritage and the Arts, Canberra.

Schwarz M.P., Fuller S., Tierney S.M., Cooper S.J.B. (2006) Molecular phylogenetics of the exoneurine allodapine bees reveal an ancient and puzzling dispersal from Africa to Australia, Syst. Biol. 55, 3145.

Simpson S.R., Gross C.L., Silberbauer L.X. (2005) Broom and honeybees in Australia: An alien liaison, Plant Biol. 7, 541-8.

Steffan-Dewenter I., Schiele S. (2008) Do resources or natural enemies drive bee population dynamics in fragmented habitats? Ecology 89, 1375-1387.

Stout J., Morales C.L. (2009) Ecological impacts of invasive alien species on bees, Apidologie 40, 388409.

Tomassi D., Miro A., Higo H.A., Winston M.L. (2004) Bee diversity and abundance in an urban setting, Can. Entomol. 136, 851-869.

Walker K.L. (2008) Carder bee (Afranthidium (Immanthidium) repetitum) pest and diseases image library. [online] http://www.padil.gov.au (accessed 30 January 2009).

Zayed A. (2009) Bee genetics and conservation, Apidologie 40, 237-262.

Zayed A., Packer L., Grixti J.C., Ruz L., Owen R.E., Toro H. (2005) Increased genetic differentiation in a specialist versus a generalist bee: implications for conservation, Conserv. Genet. 6, 1017-1026. 